\title{
Current Conditions of Open Mining of Mineral Fields of Kazakhstan
}

\author{
Khaini-Kamal Kassymkanova*, Gulnar Jangulova \\ Mining Institute after K. SatpaevD.A. Kunay ev,Almaty, Kazakhstan
}

\begin{abstract}
The paper contains the review of issues of completeness and quality of mineral mining at the opencast mines and creation of geomechanical justification of systems with internal piling. Current mining production is characterized by the increase of share of open mining of mineral resources, the ratio of which in the world mineral mining is nearly $70 \%$. Capacit ies of mining co mpanies keep on growing, production processes are being intensified; depth and periods of operation of open mines are being increased. In these conditions, issues of increase of economic efficiency and environmental safety of mining operations become of more importance; one of the most radical ways of solution of th is problem is the maximum use for location of overburden rock and production waste from the waste quarry area as a volume man-caused resource. The work contains the analytical review of the current state of open mining of mineral resources of Kazakhstan, sequence of mining operations with internal piling, sequence of formation and development of internal dump, optimal parameters of dumps (volu me, height, stratification, angles of dips) as well as the stability of inactive pit edge before and after its loading with embankment.
\end{abstract}

Keywords Open Method of Mineral Field Development, Metallurgy, Technology of Development

\section{Introduction}

Open method of mineral field develop ment (OMFD) that has been mainly developed since the middle of XX century keeps on remaining the basic one in the majority of mining countries.

At present time the specific weight of the open method of mineral field development proves that this general direction of development of mining branches is still saved for the purpose of provision of fuel and minerals needed to satisfy the needs of power system, ferrous and non-ferrous metallurgy, chemical industry, and construction branch.

The source of raw materials and minerals for coal industry with open method of their development in CIS is based on the fields situated in the eastern regions of the country (main ly Kansko-Achinskiy, Kuznezk and Ekibastuz basins), where nearly $98 \%$ of geological reserves of coal suitable for open mining is situated.

Iron ore mining with open method is concentrated at the fields of Ukraine (Krivorojskiy basin), Center (Kursk magnetic anomaly), Kazakhstan (Sokolovsko-Sarbaiskoye, Kacharskoye, Lisakovskoye, Ayatskoye fields) and Ural. Mining of non-ferrous metals with open method is mainly realized in Siberia and Kazakhstan.

* Corresponding author:

khaini_kamal@mail.ru (Khaini-Kamal Kassymkanova)

Published online at http://journal.sapub.org/mining

Copyright (C) 2012 Scientific \& Academic Publishing. All Rights Reserved
Abroad approximately $30 \%$ of coal, nearly $75 \%$ of ferrous ores, up to $80 \%$ of non-ferrous metals, overly $90 \%$ of non-metal minerals (asbestos, graphite, kaolin, mica, talc) almost $100 \%$ of nonmetal construction materials are mined with the use of OMFD.[1].

Increasing demands of Kazakhstan in fuel and minerals are satisfied due to the open method of mining and characterized by the application of highly productive equipment and new technological solutions in the production.

In view of depletion of ore reserves buried at accessible depth, the main direction of develop ment of mining industry will be further development and improvement of open method of minerals development that is related to the need of operation of fields with complex mining and geological conditions, large (down to $700 \mathrm{~m}$ ) depth of development and significant (more than 40-50 years) life time of pit walls.

Today in the Republic 35\% of copper-containing ores are developed with open mining, in 2012, the share of open method willbe increased up to $65 \%$, in $2015-$ up to $76 \%$, in 2020 - up to $79 \%$, and in 2025 it will reach $84 \%$ due to the development of the largest fields of the corporation "Kazahmys", "Aktogai" and "Boschekul". In Aktogay it is planned to mine 50 million tones of ore per year, in Boschekul - fro $\mathrm{m} 8$ to 14 million tones/year. The depth of the open mine "Aktogai" in final contour will be $700 \mathrm{~m}$, open mine "Boschekul" - up to $400 \mathrm{~m}$. The volume of rock mass will be: for Aktogai - $30 \mathrm{mln} . \mathrm{m}^{3} /$ year, for Boschekul - 15 $\mathrm{mln} . \mathrm{m}^{3} /$ year. 
Table 1. Main characteristics of open mines of Kazakhstan

\begin{tabular}{|c|c|c|c|c|c|c|}
\hline \multirow[b]{2}{*}{ Characteristics } & \multicolumn{6}{|c|}{ Open mines of Kazakhstan } \\
\hline & $\begin{array}{l}\text { Sar-bai-ski } \\
\text { y iron ore }\end{array}$ & $\begin{array}{l}\text { Kurjun-kulskiy } \\
\text { Iron ore }\end{array}$ & $\begin{array}{l}\text { Nikola-evskiy } \\
\text { Copper, lead, } \\
\text { zink }\end{array}$ & $\begin{array}{l}\text { Coal open } \\
\text { mine } \\
\text { "Boga-tyr" }\end{array}$ & $\begin{array}{l}\text { Jitika-rinskiy } \\
\text { asbestos open } \\
\text { mine asbestos } \\
\text { open mine }\end{array}$ & $\begin{array}{c}\text { Iron } \\
\text { manganous } \\
\text { open mine } \\
\text { "Jo-mart" } \\
\text { etc. }\end{array}$ \\
\hline 1 & 2 & 3 & 4 & 5 & 6 & 7 \\
\hline $\begin{array}{l}\text { 1. Annual product ion of ore, thousand } \\
\text { tones }\end{array}$ & 14000 & 1500 & 4660 & 30000 & 2000 & 429 \\
\hline 2. Length on top, $\mathrm{m}$ & 3250 & 1800 & 1540 & 5260 & 3700 & 1600 \\
\hline 3. Width on top, m & 2250 & 1500 & 1470 & 4560 & 1350 & 260 \\
\hline 4. Depth, m & 420 & 140 & 340 & 205 & 255 & 65 \\
\hline $\begin{array}{c}\text { 5. Angle of non-working pit wall, } \\
\text { degree. }\end{array}$ & $36-40$ & 35 & $32-36$ & $37-42$ & $27-32$ & $25-33$ \\
\hline 6. Method of development & \multicolumn{5}{|c|}{ Internal and external trenches } & $\begin{array}{l}\text { Internal } \\
\text { trenches }\end{array}$ \\
\hline 7. Developmentsystem & \multicolumn{6}{|c|}{ Sinking } \\
\hline 8. Technology of development & \multicolumn{3}{|c|}{ Cyclic } & $\begin{array}{l}\text { Cyclic and } \\
\text { flow }\end{array}$ & \multicolumn{2}{|c|}{ Cyclic } \\
\hline 9. Kind of transport complex & \multicolumn{2}{|c|}{ Vehicle and railway } & Vehicle & $\begin{array}{l}\text { Vehicle, } \\
\text { railway, } \\
\text { conveyor }\end{array}$ & $\begin{array}{l}\text { Vehicle and } \\
\text { railway }\end{array}$ & Vehicle \\
\hline 10. Gradient of railway, ppm & \multicolumn{2}{|c|}{$36-40$} & - & 40 & $36-40$ & - \\
\hline 11. Gradient of vehicle roads, ppm & \multicolumn{6}{|c|}{$80-100$} \\
\hline
\end{tabular}

Nearly $35 \%$ of copper ores are mined at the open mines of Northern Jezkazgan ore pit, open mines "Nikolaevskiy" and "Shemonaih inskiy" of Eastern Kazakhstan copper plant and "Konyrat" of Ba lkhash mining and metallurg ical plant. Since 2003 new powerful open mine "Nurkazgan" started to operate at Samara copper field near Temirtau city. The designed depth of the open mine is $600 \mathrm{~m}[2]$.

The main characteristics of some open mines of Kazakhstan are shown in table 1.

Along with the increase of the depth of open mines, mining and geological conditions become complicated that leads to various kinds of deformations and landslides of pit walls. This in its turn significantly damages the mining company to the point of its shutdown. Therefore the issues of effective and safe development of open mines, justification of borders of open excavations, provision of stability of pit walls, optimization of mining volume with due account to the market relations, quality management of the mined mineral resources, recla mation of dumps and disturbed lands etc are still essential.[3].

\section{Discussion}

Recently the basic research on the issues of open pit mining is directed at the solution of various environmental aspects, at the same time the issues of development of resource saving technologies of piling require further research.

Wastes of mineral mining represented by the overburden are mainly placed on the surface of the open mine or in its open area. External waste dumps alienate significant land resources deforming the relief and negatively affecting the environment.

In Kazakhstan more than 26 billion tones of production wastes have been accumulated at the dumps, which are increased by 1 billion tones every year. Out of these waste, the most part $(58 \%)$ includes the wastes of ferrous and non-ferrous metallurgy. Non-ferrous metallurgy of Kazakhstan is represented by 24 companies of three main segments of industries: copper and aluminum, lead and zinc, gold and rare metals.

Development of open mines is accompanied with constant increase of distances of transportation of the overburden to the external dumps and therefore the costs for piling. In particular, this is typical for railway dumps which, in view of low values of gradients passed by this transport, are made at significant distances from open mines by low layers and on large areas. In other words, technical characteristics of the railway transport predetermine the two-dimensional 
construction of dumps for the overburden and large areas of disturbed lands several times exceeding the land allotment of open mines.

To smaller degree this is referred to the most popular at present time vehicle and bulldozer dumps, however in this case also the distance of rock transportation to the dumps along the surface is often much more than at the open mine itself, and land areas allocated for du mps are co mpared to the area of the open mine over the surface or exceeds it several times. By construction, external vehicle and bulldozer du mps can be called height-two-dimensional ones. They are formed in one layer or several layers the total height of the dump (layer) is $100-120 \mathrm{~m}$ and more.

Along the deepening and enlargement of open mine, the cost for formation of two-dimensional (railway) and height-two-dimensional (vehicle and bulldozer) dumps, besides, land areas under them will be increased, in view of which the is sue of improvement of piling technology will be crucial.

At present time in view of ever increasing requirements of economic efficiency and environmental safety of mining operations, one of the most radical ways of location of the overburden and production wastes is the maximum use of internal piling of the open mine. Potential opportunities of the resource under question are proved for instance by the fact that the share of internal piling at the operating coal mines does not exceed $30-35 \%$, i.e. the main volume of the overburden is located at external dumps along with the withdrawal of land lots. One of the main reasons of the limited internal piling at the open mines, in particular at large depth and small sizes in the plane, is insufficient knowledge of issues of formation and rational use of the open area of open mines. The issues of the use of the open area of open mines for the storage of the overburden and production wastes have been already considered by the mining scientists and specialists[4]. At that, traditionally the area of application of technologies with the use of the open area in both domestic and foreign practice is mainly refers to horizontal and flat (up to $10-12^{0}$ ) fields. The ways of increase of volume of internal piling must be searched by means of creating the mining methods ensuring stability of internal dumps on more inclined grounds.

At that geological characteristics of rocks, mining and technicalconditions, technology of operations at the working place, safety requirements and time of operation are determined by the basic parameters of internal dumps such as quantity and height of layers, minimal sizes in the plane. Besides, the applied parameters of the dump should ensure the opportunity of its setting out in case of temporary storage of the rock.

At the development of flat and steeply inclined fields much experience was gained in the field of piling in various mining and technical conditions (stable and unstable ground, plain, undulating land and highland relief, layering), at various location relative to contours (external and internal) and various methods of safety provision (conservation of stability and controlled shifting).
The classification of dumps developed by the member of Academy N.V. Melnikova contributes to the selection of rational process charts of piling for steeply inclined fields of certain mining and technical conditions and correct organization of dumping operations in open mines [5].

Further solution of the problem requires the development of scientific grounds of technologies of open pit mineral mining with maximumpossible internal piling in wide range of mining and geological and mining and technical conditions.

Sequence of mining operations with internal piling determines the progressive advance of the dump along with the progress of field development.

However the formation of internal dumps requires the thorough study of issues related to the proper stability of internal pit walls loaded with embankments of internal dumps. At that, geomechanical justification of the piling place, sequence of piling, its parameters (volume, height, layers, angles of dips) is needed. Since the disturbance of stability of the system can lead to emergencies (collapse of pit wall, landslides) and to temporary shutdowns or reductions of mining in the period of emergency liquidation.

\section{Results}

Thus, analys is of experience of mineral field development proves that the rational use of open area, ensuring the optimal location of the overburden at the least costs for their transportation and storage as well as the search for reduction of adverse environmental impact of mining production, is one of the main reserves of increase of economic efficiency and mining safety.

Another factor, that is worthy of consideration, is the technology of mining operations in the Kazakh oil fields, worked by open method, yielding counterparts overseas in terms of mine technical and environmental efficiency and safety. At present, due to the ever increasing demands for greater economic efficiency and environmental safety of mining operations, it is important and urgent to find solution to maximize space for the waste of mining fields. Search for solutions to mentioned problems is mainly in the direction of creating a method of mining to ensure the sustainability of internal piles on more sloping grounds, as well as increasing the use of the mouldboard in mining fields. To address the problem, a series of scientific work is, currently, underway. One of them is the development of a scientific basis for the further exploration of resource-saving technologies and open mining with maximum internal stacking. It is important to consider such tasks as:

- Geo-mechanical study of mining development;

- Optimization of the parameters of the mining field's spacer;

- Analytical calculations of volumes of overburden;

- Justification quarry transport and all processes;

- Sustainability-p it dumps and sides;

- Calculation of the environ mental risks. 
One of the main parameters in the security of these conditions is the stability of pit walls, which provides optimum angle side. The Kazakh mines, such as asbestos 'Zhitikara', sections of JSC "Shubarkol", "Bogatyr Coal", LLP "Karazhira Ltd» and others can skip the internal stacking. Positive aspect in this case is the fact that such a resource-mining system reduces the cost of transportation of overburden, reduces the cost of land reclamation from external piles, which cons equently leads to lower production costs. This raises the issue of geo-mechanical character that is the sustainability of pit slopes and internal dumps. For each particular field it is necessary to study sustainable geo-mechanical parameters of boards and benches.

\section{REFERENCES}

[1] V.L.Yakovlev. Condition, problems and ways of improvement of open mines // Mining magazine 2009-№11, pp.11-14

[2] Sapakov E.A. and others. Development of cyclic and flow technology for open mines of the corp oration "Kazakhmy s" // Mining magazine. - 2005 - №5 (special edition).

[3] I.V.Melik - Gaikazov., A.I. Vinogradov and others. Equipment and technology of formation of high dumps of overburden rocks // Mining magazine 2009-№11, pp.64-69

[4] Rjevskii V.V. Open pit mining. 4.2. - M. Nedra, 1985. - 549 p.

[5] Melnikov N.V. Development of mining science in the field of open pit development of the USSR fields.-M.: Gosgortehnadzor, 1961. - $236 \mathrm{p}$.

[6] A. Srikant, C. Brannon, D. C. Flint, and T. Casten. Geotechnical characterization and design for the transition from the Grasberg open pit to the Grasberg block cave mine, Proceedings of Rock Mechanics Conference, Taylor\&Francis Group, London, 2007.

[7] Chebakov A. Stability of open pit edges (статья)// Challenges and Solutions in Mineral Industry. Freiberger Forschungsforum 60. 2009. - P. 155-158.

[8] Meagher, S. A. Abdel Sabour, and R. Dimitrakopoulos. Pushback design of open pit mines under geological and market uncertainties, The Australasian Institute of Mining and Metallurgy, Spectrum Series No. 17, 2010.

[9] Castendyk D.N., Mauk J.L., Webster J.G. A mineral quantification method for wall rocks at open pit mines, and application to the Marpha Au-Ag mine, Waihi, New Zeland // Applied Geochem. 2005. V. 20. P. 135-156.

[10] Pevzner M.Ye. Geomechanics: Higher school texbook /Pevzner M.Ye., Iofis M.A., Popov V.N.; 2 edition. M.:Izd-vo Moskovskogo gosudarstvennogo gornogo universiteta,2008. -438 p.: illustrated.

[11] Sobko B.Ye. Improvement of titanium-zirconium placer open-cast mining technology: Monograph / SobkoB.Ye. Dnepropetrovsk: Nacionalnyy gornyy universitet, 2008. $167 \mathrm{p}$.

[12] Prokopenko V.I. Improvement of technological solutions of open-cast fields reprocessing aiming land saving/V.I. Prokopenko, T.N.Mormul/Ecology and Nature Management. -2010. - Issue 13.- P. 147-154.

[13] Analysis of stability loss in open - hit slopes and assessment principles for bard, tectonically-stressed rock mass es / Ko zyrev A.A., Reshetnyark S.P., Maltsev V.A., Rybin V.V.// Slope stability in surface Mining. Charter 27 in section 2 - Littleton, Colorado: SME. 2001. - P. 251-256. 